\title{
OIL AND GAS OPERATIONS UNDER EXTREME CONDITIONS IN THE COLD NORTH
}

\author{
O.T. GUDMESTAD \& T. MARKESET \\ University of Stavanger, Stavanger, Norway.
}

\begin{abstract}
Norway's oil industry is shifting attention toward the north, to the Barents Sea. This means it must adjust to temperatures down to $-30^{\circ} \mathrm{C}$, storms, sleet, and snow, and possibly to drift-ice in the case of operations toward the north and east of these seas. Furthermore, operations during winter time will be carried out in the blackest night as the sun is away for several weeks. We have some information about the climate; however, compared with our expertise from the southern Norwegian continental shelf, we know little about how to run an offshore production installation in a cold climate.

Keywords: Cold climate, High North, oil and gas developments, operations.
\end{abstract}

\section{INTRODUCTION}

We could imagine changing a tire on our car in freezing weather, snow, and darkness; that is a way of visualizing the challenges facing oil companies seeking to produce oil and gas from the far north of the Norwegian continental shelf (NCS).

Weather, winter darkness, vast distances, and safety and emergency response challenges for petroleum facilities in the Barents Sea will all be more extreme than in the North Sea. Compared with our expertise from the southern NCS, we know little about how to run an offshore production installation in a cold climate (Fig. 1).

These are aspects of considerable concern for research and it is required to find solutions to these in order to develop fields in areas with Arctic conditions.

\section{GOVERNMENT HAS OPENED THE BARENTS SEA FOR EXPLORATION AND PRODUCTION}

The Norwegian government opened the southern part of Norway's Barents Sea sector for petroleum operations in the early 1980s (Fig. 2). Activity was high but finds few, so interest declined. But enthusiasm for these waters has recovered sharply in the recent past, particularly after the Johan Castberg (Skrugard) oil discovery was made during 2011.

Promising seismic data, several large oil and gas finds, and new technology mean that a growing number of oil companies are seeking opportunities to explore further north on the NCS. Norway's Statoil has in particular increased its spending on technology for Arctic waters. The increased interest in the far north also reflects government policies, promoting Barents Sea activities.

Norway currently has one gas production facility operating in the southern Barents Sea. This Snøhvit field has been on stream since 2007. Furthermore, operator Eni will bring its Goliat oil development into production in 2015. Those fields lie north-west of Hammerfest, 140 and $85 \mathrm{~km}$ from land, respectively. Johan Castberg, for its part, is located roughly $100 \mathrm{~km}$ further north-west from Snøhvit and work is ongoing to identify a technical and economical field development solution, also incorporating satellite fields. 


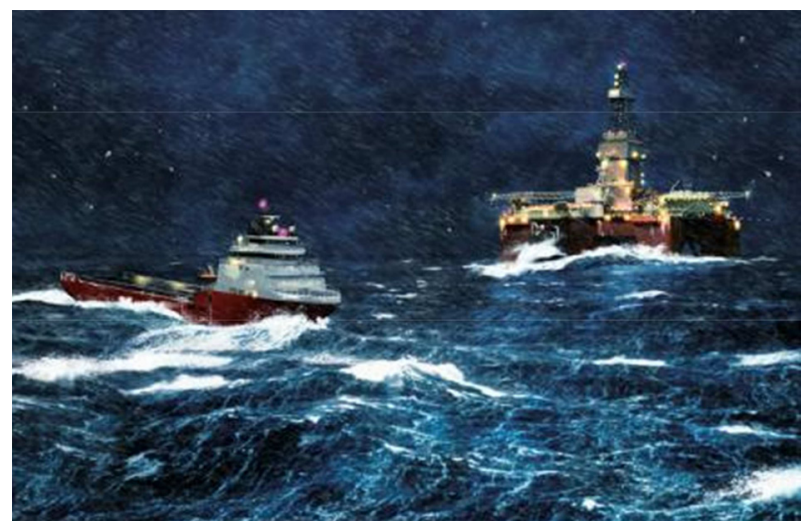

Figure 1: Freezing temperatures, icing, snow, and an unpredictable climate have a bigger impact on the operations of a platform in the Barents Sea than in the North Sea (Illustration: Ole Andre Hauge).

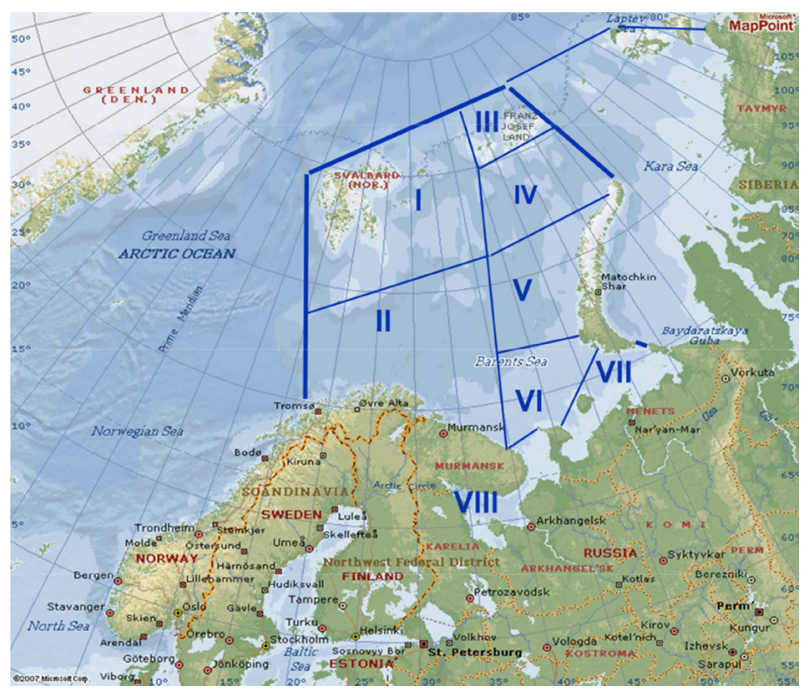

Figure 2: Barents Sea regionalization; south western Barents Sea is region II [1].

\section{UNPREDICTABILITY}

The weather is the main challenge for impatient oil companies and official agencies; it is quite unpredictable for much of the year, which is special about the far north. Weather conditions in these waters differ from the North Sea in terms of low temperatures, icing, fog, heavy snowfalls, and sudden changes [2] (Fig. 3).

The North Sea weather is easier to forecasts and we know that when a low pressure area over Iceland moves east, it will bring rough weather and one can plan operations accordingly. In the Barents Sea, however, deep troughs of low pressure develop at the interface between ice and open water. These cannot be predicted, and may create sudden storms and hurricanes.

Wind and waves have much to say for the safety of shipping, fishing, and offshore operations. So accurate weather forecasts are important; with fewer monitoring stations gathering data in the Arctic forecasting in the Barents Sea is less accurate than in the North Sea. 


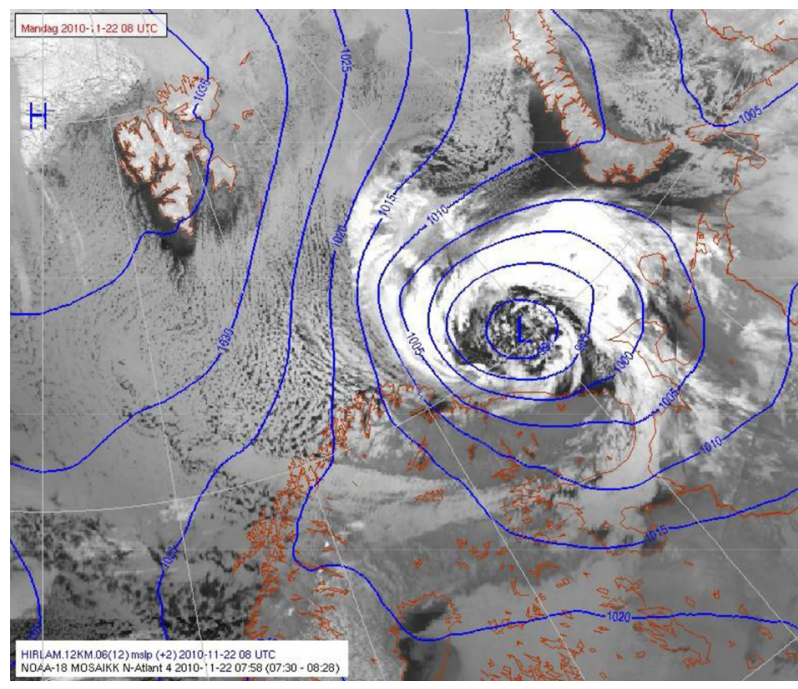

Figure 3: Polar low pressures in the Barents Sea (Courtesy NOAA).

\section{LONGER TIME NEEDED FOR MANY ACTIVITIES-PARTS OF THE YEAR}

The further north you go, the longer the winter becomes and the shorter the summer season. A good deal of offshore work must necessarily be performed during the summer season. However, the weather in these brief months may not allow all planned activities to go ahead. The consequences of 'waiting for weather' will be delays and potentially increased costs for the development.

Arctic conditions can also mean that equipment fails or breaks down in unfamiliar ways, or more frequently than is the case in warmer regions. Repairing broken equipment is also likely to take more time; for example, if the equipment is covered in snow or ice we will have to dig it out before the job can begin. It is also harder to work in a temperature of $-30^{\circ} \mathrm{C}$ than in $10^{\circ} \mathrm{C}[3,4]$. Putting small screws into place, for example, is a slow business with gloves on. Furthermore, increased amount of preventive maintenance may be necessary to make sure that the equipment functions properly. Predictive maintenance using condition monitoring with advanced sensors, software, and hardware may be a viable alternative to ensure quality performance of the installed production facilities. The more frequently equipment breaks down and the longer it takes to repair, the less time will be available for producing oil and gas [5]. This is a critical issue as when we invest in a production facility for the far north, it must be up and running for as much of the time as possible so that we can produce profitably. A huge problem would, therefore, be faced if an installation fails to cope with the local climate. We would be left with a massive and expensive machine, which yields little.

\section{WINTERIZATION}

The issues of concern could be characterized by one word: winterization-tailoring equipment and workplaces so that they can operate normally in a harsh winter climate [6]. Much could be different in the far north, including the need for special steels and equipment when temperatures fall low enough: plastics, rubber, metals, and lubricants are examples of materials that change their properties under extreme cold, and which must be adapted to the Arctic environment [3]. 
Furthermore, electrical systems, sensors, cables, valves, motors, and pumps must all be specially manufactured. Piping, tanks, and pumps containing liquids that could freeze have to be kept warm even if the installation shuts down to avoid being burst by frozen fluids.

An increased need to heat equipment and facilities and to provide lighting will boost energy consumption on installations, including heating cables in corridors and on helidecks, for instance.

\section{ENCLOSED AREAS}

The cold means that more equipment must be enclosed on units working in the Barents Sea than further south [3,7]. And that in turn calls for more ventilation to prevent gas accumulations with potential for ignition and explosions. Research is ongoing to identify safe layout as a balance between enclosing the modules and providing ventilation.

Outfitting facilities in the far north will in any case be more complex because of the need for heating and increased use of sensors to measure equipment condition. The companies will therefore have to rely more on remote monitoring of and support for equipment via centers located in such places as Troms $\varnothing$ or as far away as Stavanger [8]. Real-time diagnosis of systems will be crucial, making use of the Internet, fiber-optic cables, satellites, and specially developed sensors. A key role will also be played by experts who could be located either at suppliers or in service companies in, for example, Germany, Italy, the United States or elsewhere.

On the other hand, equipment protected through proper winterization technology (such as being enclosed, with heat tracing and special designs) and better monitored with the aid of sensors may actually be more reliable and break down less frequently than in warmer waters.

\section{DISTANCES}

Companies must also take account of longer distances to market for delivering oil and gas as well as for providing operational, maintenance, and support services [7]. Operators have to make more thorough preparations, keep more spare parts on hand, and perhaps have more and better expertise on board the production facility [9]. This will all add to costs.

In addition, facilities operating above the Arctic Circle must take 24-h winter darkness into account. An important question which needs to be researched is also how the perpetual winter darkness affects work processes on an offshore facility.

\section{ICE}

The south-western Barents Sea is not much troubled by sea ice. We are accordingly looking at opportunities for field development and operation in an environment largely free of sea ice, but where drift ice must nevertheless be expected. Such ice floes may weigh several hundred tons. They can be tossed around by waves and driven with great force against an installation, causing serious damage. In case of serious ice challenges, the facilities may have to be disconnected from the production units on the seafloor and moved away.

The present production equipment is designed for a collision with drift ice and that will limit the time we can drill in the northern Barents Sea-unlike year-round drilling in the North Sea.

The Shtokman gas field in the Russian sector of the Barents Sea, for example, lies in an area affected by both drift and pack ice. Technical solutions for the development have proved to be too costly to embark on the development project. Pack ice involves extreme forces. It can exert pressure from every direction. A platform placed in the middle of it must be able to withstand such forces or to leave the location. Therefore, we should not aim 
to position facilities on the NCS in pack ice-in other words, in the northern Barents Seauntil further technology development has taken place. We, accordingly, believe in a gradual advance northward, in order to learn from conditions at each stage and to keep in step with technological progress.

Although operations have begun in pack ice off Russia and Alaska, we should aim first and foremost to research and develop production solutions for the south-western Barents Sea. This is also an area with extreme weather conditions and below-freezing temperatures, but where drift ice only appears only occasionally.

\section{ACHIEVABLE DEVELOPMENTS}

Before deciding to build oil installations for the northern Barents Sea, we must know whether this is achievable. Plant availability must be satisfactory so developments be profitable [10]. We must also think about how to prevent accidents and how to respond should one nevertheless occur [11].

We must ensure that equipment, organization, and working methods are tailored to the Arctic environment, and thereby designed to reduce the probability of undesirable incidents. We must, for example, be certain that the emergency response and evacuation systems work in the Arctic.

\section{THE THREAT}

Furthermore, we are concerned that oil spills in the far north pose a big threat to the vulnerable environment in these waters. Much of the existing oil spill clean-up equipment has not been designed to operate in a cold climate and drift ice, and we must accordingly come up with better methods for collecting any oil spill in waters where sea ice could be encountered.

The role of the engineering society is to make it technically and organizationally possible to operate in the various sea areas when the government decides to set things going. We must, for example, build even more safely in the Barents Sea than in the North and Norwegian Seas, and reduce the probability of oil spills even further and devote extensive resources and work to avoiding oil spills in these regions.

\section{ACKNOWLEDGMENTS}

The authors acknowledge use of citations from an interview with the authors; 'Working under extreme conditions', by journalist Karen Anne Okstad as presented in Science Nordic on December 11, 2012: http://sciencenordic.com/working-under-extreme-conditions

\section{REFERENCES}

[1] DNV, Det Norske Veritas, Barents 2020 Phase I. Technical report No. 2008-0664, Ice and Metocean, Barents 2020 Project. DNV: Oslo, Norway, 2008.

[2] Gudmestad, O.T., Marine construction and operation challenges in the Barents Sea. International Journal of Ship Research Technology, 60(3), pp. 128-137, 2013. doi: http:// dx.doi.org/10.1179/str.2013.60.3.003

[3] Larsen, A. \& Markeset, T., Mapping of operations, maintenance and support design factors in arctic environments. The Proceedings of the European Safety and Reliability Conference (ESREL 2007), Stavanger, Norway, ISBN 978-0-415-44786-7, June 25-27, 2007.

[4] Kumar, R., Barabady, J., Markeset, T. \& Kumar, U., Improving maintainability in extreme cold climatic conditions. International Journal of Performability Engineering, 8(5), pp. 563-572, 2012. 
[5] Markeset, T., Design for high performance assurance for offshore production facilities in remote harsh and sensitive environment. Quarterly Journal of the Operational Research Society of India, OPSEARCH, 45(3), pp. 275-290, 2008.

[6] DNV, Det Norske Veritas, Winterization for Cold Climate, Oslo, Norway, DNV-OSA201, 2013.

[7] Homlong, E., Panesar, S.S., Kumar, R. \& Markeset, T., Influence of arctic environment on reliability, availability, maintainability and supportability. The Proceedings of Condition Monitoring and Diagnostic Engineering Management (COMADEM2011), Stavanger, Norway, ISBN 0-9541307-2-3, May 30-June 1, 2011.

[8] Markeset, T., Kumar, R. \& Kumar, U., Remote operations and maintenance support services: A conceptual framework, Proceedings of the Mine Planning and Equipment Selection Conference (MPES2007), Bangkok, Thailand, December 11-13, 2007.

[9] Ayele, Y.Z., Barabadi, A. \& Markeset, T., Spare part transportation management in High North. The Proceedings for the 22nd International Conference on Port and Ocean Engineering under Arctic Conditions (POAC2013), Espoo, Finland, June 9-13, 2013.

[10] Barabadi, A. \& Markeset, T., Reliability and maintainability performance under Arctic conditions. International Journal of System Assurance Engineering and Management, 2(3), pp. 205-217, 2011, DOI: 10.1007/s13198-011-0071-8.

[11] Jacobsen, S.R. \& Gudmestad, O.T., Evacuation from petroleum facilities operating in the Barents Sea, Paper OMAE-2012-83329. Proceedings of OMAE, Vol. 1, Rio, 2012. doi: http://dx.doi.org/10.1115/omae2012-83329 